\title{
Effects of topical $2 \%$ cyclosporine A on the corneas of dogs subjected to lamellar keratoplasty with a graft of equine pericardium preserved in glycerin. Clinical and morphological evaluation
}

\author{
Efeitos da aplicação tópica da ciclosporina A a $2 \%$ sobre a córnea de cães submetidos à \\ ceratoplastia lamelar com implante de pericárdio de eqüino preservado em glicerina. \\ Avaliação clínica e morfológica
}

\author{
Roseli Borges Teixeira ${ }^{1}$ Paulo Sergio de Moraes Barros ${ }^{2}$ Maria Cristina Martins ${ }^{3}$
}

\section{ABSTRACT}

The effects of topical $2 \%$ cyclosporine A on the cornea of dogs subjected to experimental lamellar keratoplasty with an equine pericardial graft were evaluated. Ten dogs were grouped to be evaluated 3, 7, 15, 30 and 60 days after surgery. Animals received bilateral grafts followed by the application of a $2 \%$ cyclosporine A ointment on the left eye (treated eye) and the ointment base on the right eye (control eye) twice a day. The ophthalmic evaluation showed profound bilateral blepharospasm, photophobia and a mucous secretion until the $7^{\text {th }}$ day after surgery; corneal vascularization starting in the limbus was observed as early as the $3^{\text {rd }}$ day in both eyes; opacification and vascularization were more intense in the treated cornea on days 15 and 30 after surgery. Vascularization was still evident on the $60^{\text {th }}$ day, and looked similar in treated eyes and control eyes. The histologic evaluation showed a complete bilateral reepithelization and corneal vascularization three days after the surgery; intense vascularization in both eyes on days 15 and 30, that was much more pronounced in the treated cornea; and a bilateral predominance of polymorphonuclear cells until day 15, and mononuclear cells on day 30. Intact epithelium and stroma with new vessels, as well as graft absorption, in both eyes, were seen on the $60^{\text {th }}$ day. The lamellar keratoplasty with equine pericardial graft was an effective model to study the inflammatory kinetics and corneal vascularization phenomenon. In this study, cyclosporine A did not inhibit corneal vascularization and it did not interfere in the corneal cicatricial process.

Key words: cyclosporine, cornea, pericardium, vascularization, keratoplasty, dogs.

\section{RESUMO}

Foram avaliados os efeitos da ciclosporina $A$ a $2 \%$ sobre a córnea de cães submetidos à ceratoplastia lamelar experimental com implante de pericárdio de equino. Dez cães foram divididos em grupos para estudo aos três, sete, 15, 30 e 60 dias de pós-operatório, recebendo implantes bilaterais e em seguida aplicação da pomada com ciclosporina A a $2 \%$ no olho esquerdo (olho tratado)e somente a base da mesma pomada no olho direito (olho controle), duas vezes ao dia. À avaliação oftalmológica observou-se, bilateralmente, blefarospasmo, fotofobia $e$ secreção mucosa evidentes até 7 dias de pós-operatório; início de vascularização a partir do limbo aos três dias, bilateralmente; opacidade e vascularização mais intensos em córnea esquerda aos 15 e 30 dias; vascularização ainda evidente, bilateralmente, com aspecto semelhante aos 60 dias. À avaliação histopatológica observou-se, bilateralmente, completa reepitelização e vascularização aos três dias de pós-operatório; vascularização intensa aos 15 e 30 dias, bilateralmente, porém acentuada na córnea esquerda; predomínio de polimorfonucleares até os 15 dias $e$ mononucleares aos 30 dias, bilateralmente; epitélio e estroma integros com vasos ainda evidentes e implante incorporado ao estroma, bilateralmente, aos 60 dias. A utilização do implante de pericárdio de equino em ceratoplastias lamelares em cães constitui uma técnica eficaz, aplicável ao estudo da cinética inflamatória e fenômeno de vascularização. A ciclosporina A a $2 \%$ não inibiu ou diminuiu a formação vascular na córnea e também não interferiu no processo cicatricial neste estudo.

Palavras-chave: ciclosporina, córnea, pericárdio, vascularização, ceratoplastia, cães.

${ }^{1}$ DVM, MSc, Laboratory of Experimental and Comparative Ophthalmology, Department of Surgery, Faculdade de Medicina Veterinária e Zootecnia, Universidade de São Paulo, São Paulo, SP, Brazil. E-mail: roseli.teixeira@utp.br.

${ }^{2} \mathrm{DVM}, \mathrm{PhD}$, Laboratory of Experimental and Comparative Ophthalmology, Department of Surgery, Faculdade de Medicina Veterinária e Zootecnia, Universidade de São Paulo, São Paulo-SP, Brazil. Adress communications to: Rua Caiowaa, 1236 ap. 204, 05018-001, São Paulo, SP, Brazil, Fax: + 55.11.3673.2851, e-mail: pauloeye@usp.br

${ }^{3} \mathrm{MD}$, MSc, PhD, Laboratory of Ocular Pathology, Department of Ophthalmology, EPM, UNIFESP, São Paulo, SP, Brazil. 


\section{INTRODUCTION}

Corneal ulceration is very frequent and represents one of the most important eye diseases in veterinary ophthalmology. It requires quick intervention, even in the most superficial lesions, in order to avoid serious complications and preserve the vision (BROOKS, 2000). Many therapeutic attempts have been made over the years to repair the cornea in order to maintain its structure and, if possible, its transparency and function. Surgical therapeutic methods are very important in corneal ulcer cases with important corneal tissue loss, in which the only alternative is tissue substitution (BARROS et al., 1995).

Equine pericardium was successfully used in the correction of entropion and to fill the orbital cavity of dog following enucleation (BARROS et al., 1985), as well as in the repair of the sclera and third eyelid in dogs (BARROS et al., 1990). In cases of penetrating sclerokeratectomy due to limbal neoplasia (BARROS et al., 1995); keratectomy with partial iridectomy due to a perforating lesion (BARROS et al., 1995) and in lamellar and penetrating keratoplasty in dogs, it was also effective because of the perfect integration between the pericardium and the cornea and the absence of rejection phenomena (KAVINSKI, 1980; BARROS et al., 1995; BARROS et al., 1997). Although the results are good with the use of pericardium for the anatomic preservation of frail or perforated cornea, the occurrence of cicatricial reaction with leucoma and corneal vascularization may be a limiting factor to its use, especially in axial or extensive wounds, for vision may be affected.

The present trial was performed in order to evaluate the lamellar keratoplasty with an equine pericardial graft preserved in glycerin and the effects of topic cyclosporine A on these corneas of dogs, because it does not interfere in the cicatricial process of the cornea (READ, 1996); because of its potential for decreasing corneal vascularization (EPSTEIN et al., 1987; LIPMAN et al., 1992; NORRBY, 1992; BENELLI et al., 1997) and because of the beneficial results observed using topical cyclosporine A on several corneal inflammatory affections (KASWAN et al., 1989; JACKSON et al., 1991; MORGAN \& ABRAMS, 1991; READ, 1996; STEVENSON et al., 2000).

\section{MATERIALS AND METHODS}

All animals involved in this study were maintained and handled in accordance with the ARVO Statement for the Use of Animals in Ophthalmic and Vision Research. Ten mixed-breed male dogs, weighing around $15 \mathrm{~kg}$ were divided in five groups of two dogs each to be studied after 3, 7, 15, 30 and 60 days of the surgery. Preoperative ophthalmic examination included slit-lamp biomicroscopy, fluorescein strip test, Schirmer tear test, TonoPen applanation tonometry and direct ophthalmoscopy. The anesthetic protocol included premedication using intramuscular $0,2 \mathrm{mg} \cdot \mathrm{kg}^{-1}$ of $0,2 \%$ acepromazine; induction using intravenous 12,5mg. $\mathrm{kg}^{-1}$ of Tiopental; and maintenance using 1,0$2,5 \%$ of halothane in semiclosed circle rebreathing system.

A corneal wound in the upper temporal area of each cornea was produced using a $5 \mathrm{~mm}$ trephine. The lesion involved the epithelium and approximately half of the width of the stroma. A $5 \mathrm{~mm}$ diameter patch of pericardium preserved in $98 \%$ glycerin, previously hydrated using saline solution, was placed on the wound and sutured in the corneal defect in a single interrupted pattern using 8-0 nylon sutures. These procedures were first performed in the right eye, and then in the left eye of each animal.

As an immediate post-surgical procedure, a $2 \%$ cyclosporine A ointment* was applied to the left eye (treated eye) and only the base of the ointment* to the right eye (control eye), twice a day, until the end of the evaluation period. No other topical or sistemic drug was used during these periods.

The animals were submitted to ophthalmic examination with slit-lamp biomicroscopy daily, in which parameters such as blepharospasm, photophobia, ocular secretion, corneal opacification, corneal vascularization and pigmentation were analyzed. Viability, permanence and transparency of the grafts were also observed. These parameters were classified as absent, minor, moderate, intense and major. At the end of the period of study, animals were euthanized and their eyes enucleated and fixed in a $10 \%$ buffered formaldehyde solution. Sections were stained by H \& E, PAS and Masson's trichrome stain, and examined by light microscopy. Aspects such as reepithelization, edema, corneal vascularization and polymorphonuclear and mononuclear leukocyte infiltration were analyzed.

\section{RESULTS}

\section{Clinical aspects}

Blepharospasm and photophobia were observed in all animals, and were intense up to the $7^{\text {th }}$ postoperative day; they were minor on day 15 and bilaterally absent from the $30^{\text {th }}$ day on. In relation to the quali-quantitative evaluation of secretion, it was observed a bilateral predominance of serum-mucous 
type, evident from the $3^{\text {rd }}$ to $15^{\text {th }}$ postoperative day, and absent in the other observation periods, being moderate on the $7^{\text {th }}$ day.

In relation to corneal opacification, it was minor adjacent to the graft on the $7^{\text {th }}$ postoperative day;

moderate in the control cornea (Fig.1A), and intense in the treated cornea on day 15 (Fig.1B). It was still present bilaterally on day 30 (Figs.1C and D), and it was reduced on the $60^{\text {th }}$ postoperative day. A leucoma in the graft area was similar in both corneas.

Corneal vascular formation began at the limbus of the upper temporal region bilaterally on the $3^{\text {rd }}$ postoperative day; it was more evident bilaterally on day 7, intense in the control cornea (Fig.1A), and major, reaching the graft, in the treated cornea on day 15 (Fig.1B); it was also intense bilaterally on day 30 (Figs.1C and D); however, it was still prominent in the treated cornea (Fig. 1D). The appearance of both corneas was similar on the $60^{\text {th }}$ postoperative day, when corneal vessels, some suture granulomas, and excellent transparency of the cornea and partial transparency of the implant were observed. None of the corneas presented pigmentation.

\section{Histopathologic findings}

Complete bilateral reepithelization was observed on the $3^{\text {rd }}$ postoperative day, with the presence of regenerative phase epithelium, and acanthosis in the transition cornea/graft. On day 7 , the basal layer of the epithelium was starting to be defined, and on day 15 it was stratified, presenting almost normal width. The stroma had fibroblastic hypertrophy with an increase in the collagenous matrix and bilateral inflammatory infiltrate with predominance of polymorphonuclear cells. On day 30 , the epithelium presented bilaterally several polyedrical and cylindrical layers (Figs.2A and B), and complete
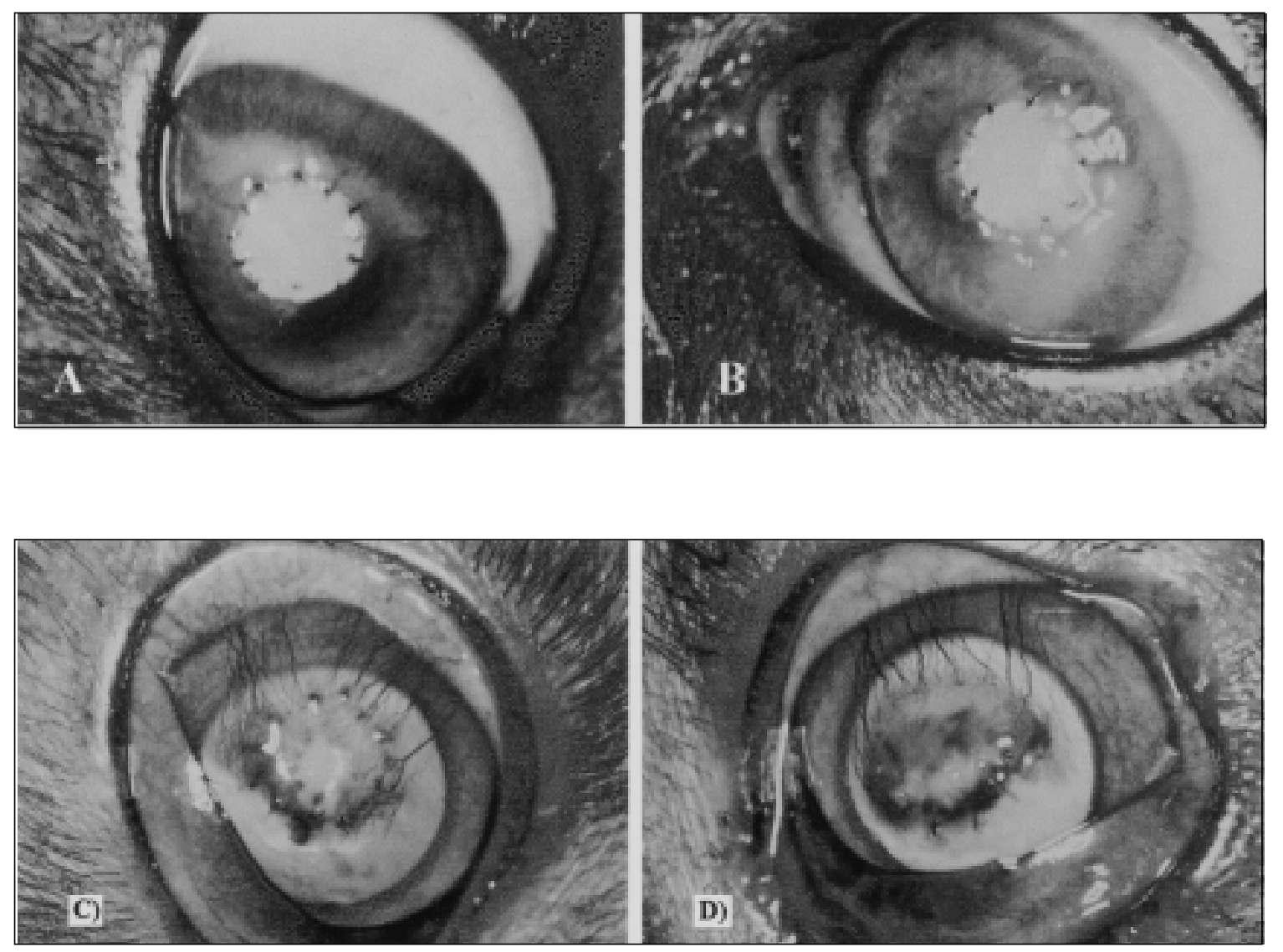

Figure 1 - A) Control cornea at day 15: mild vascularization and light edema close to the implant; B) Treated cornea at day 15: heavy vascularization and strong edema at the implante site.

C) Control cornea at day 30: intense vascularization surrounding the implant; D) Treated cornea at day 30: intense vascularization over and surrouding the implant, discret opacification close to the implant, exuberant granulation.

Ciência Rural, v. 34, n. 1, jan-fev, 2004. 


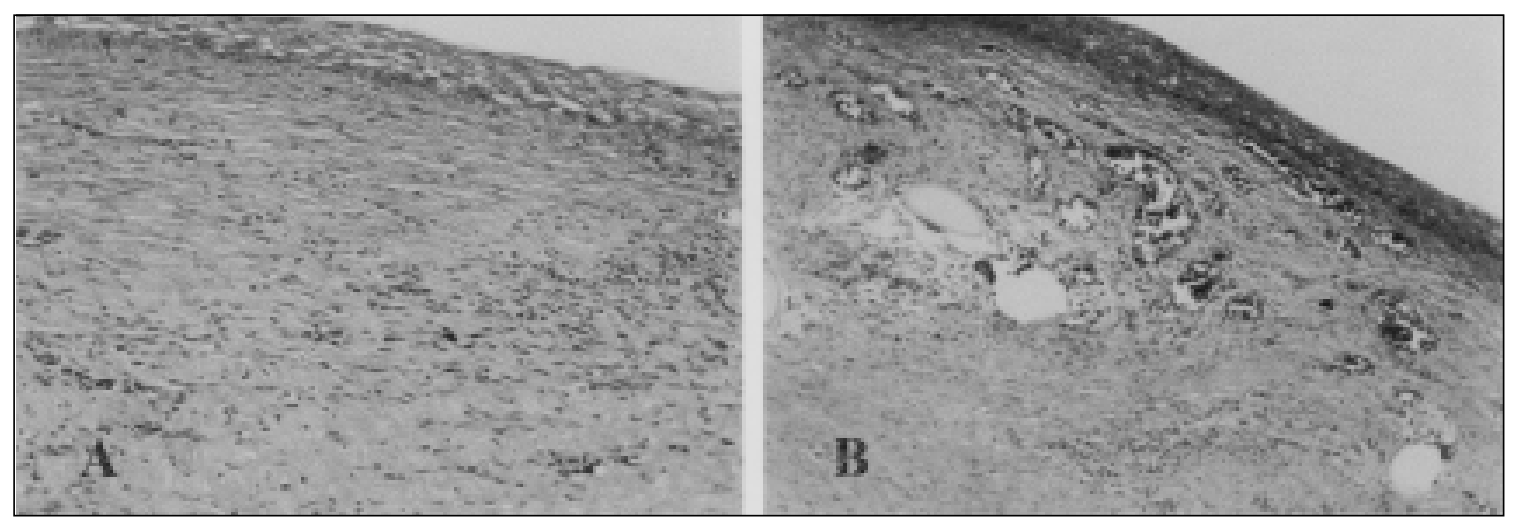

Figure 2 - A) Control cornea at day 30: epithelial edema, vessels into the implant and stroma, the pericardium is incorporated. To the stroma, new collagen fibers between the epithelium and implant; monuclear cells infiltrate predominates (H\&E X 200); B) Treated cornea at day 30:re-epithelization, epithelial edema, heavy vascularization with large vessels, pericardium incorporated to the stroma (H\&E X 200).

regeneration occurred by the $60^{\text {th }}$ postoperative day when remains of the graft were observed among the reconstituted stroma suggesting an absorption process.

Edema adjacent to the graft was observed bilaterally on the $7^{\text {th }}$ postoperative day, and was more evident on day 15 when disarrangement of the lamellae of the stroma with presence of fibroblasts and inflammatory cells could be observed. There was an increase in the width of the cornea in the keratoplasty site when compared to the intact cornea. In this phase, epithelial edema was also observed, and it was characterized by vacuolization which was also evident on the $30^{\text {th }}$ postoperative day. These events disappeared on day 60 .

Corneal vascular formation occurred associated with the inflammatory events, and vessels were observed bilaterally from the limbus towards the keratoplasty site on the $3^{\text {rd }}$ postoperative day. On day 7, these vessels took up most of the stroma, bilaterally. On day 15 , the phenomenon was intense in both corneas, with vessels in the interface graft/ stroma, inside the graft and in the adjacent stroma. On day 30, vascularization was still intense bilaterally with vessels inside the graft and in the adjacent stroma (Figs.2A and B). The vessels, however, took a greater part of the stroma of the treated corneas of the animals in this group (Fig.2B). On the $60^{\text {th }}$ postoperative day, vessels were still present in similar amount bilaterally.

Inflammatory cell infiltrate was characterized, bilaterally, by the early infiltration of polymorphonuclear cells in the adjacent stroma, in the interface and inside the graft. It was present up to the $15^{\text {th }}$ postoperative day associated with the intense vascularization in this phase. A major inflammatory setting was observed, with intra-epithelial inflammation in the treated cornea of the animals of the $15^{\text {th }}$ day group. On day 30 , a chronic inflammatory reaction was observed with the bilateral presence of mononuclear cells and rare polymorphonuclear cells in the adjacent stroma and inside the graft (Figs. 2A and $B$ ). On day 60 , a discrete mononuclear cell infiltrate was observed in the corneal stroma bilaterally.

\section{DISCUSSION}

Photophobia and blepharospasm were evident immediately after the surgery and occurred due to stimulation of the sensors epithelium and stroma nerve terminations (WARING, 1984) produced by the surgical procedure and the presence of the graft, as well as the contact of the sutures with the eyelid conjuntiva. This is a frequent finding in keratoplasties with lamellar and penetrating grafts, in which there is no burying of the suture knots. Secretion was predominantly mucous, which is present in conjunctival and corneal processes, due to the stimulation of caliciform cells; it was, therefore, expected in such a surgical procedure (STARTUP, 1984). The characteristic of the ocular secretion was not influenced by the topic use of cyclosporine A, which presents specific immunosupressing action on $\mathrm{T}$ lymphocytes, and did not interfere in the innate immune response by phagocytic cells (DIASIO \& LOBUGLIO, 1996), what explains its uncommon association with opportunistic infections (RYFFEL, 1989). 
In relation to the cicatricial process, epithelial repair was quick, and characterized by sliding and mitosis of epithelial cells in a centripetal direction (PEIFFER JR. et al., 1999). Acanthosis observed in the extremities of the implant in this study confirms the mitotic capacity of these cells (PEIFFER JR. et al., 1999). The repair of the stroma occurs more slowly, through fibroblastic proliferation. In the final phase, fibroblastic tissue decreases and collagenous fibers are reorganized in a parallel fashion, determining the intensity of the scar and the subsequent transparency of the cornea. This was observed in the later periods of evolution, with the bilateral incorporation of equine pericardium to the corneal stroma. Complete and bilateral repithelization on the $3^{\text {rd }}$ postoperative day confirms that cyclosporine A does not present adverse effects on the epithelium, during the cicatricial process in the cornea (BEHRENS-BAUMAN et al., 1986; BELIN et al., 1990).

Edema is the main responsible factor for the loss of corneal transparency (PEIFFER JR. et al., 1999) and thin vesicles are found when it affects the epithelium. When affecting the stroma, it produces diffuse mist, and is characterized by an increase in cornea thickness (SPENCER, 1996); this was bilaterally observed on day 15 and 30.

The degree of opacification is not only associated with the edema, but also to the number and concentration of inflammatory cells, to the presence or absence of neovessels and to enzyme-induced stroma necrosis (SPENCER, 1996). This may explain the higher intensity of cornea opacification on days 15 and 30 , when intense vascularization and important inflammatory infiltrates occurred, mainly in the treated cornea.

In relation to vascular phenomena, vascularization was observed bilaterally on the $3^{\text {rd }}$ postoperative day. This may be asscociated with the hypothesis that angiogenic factors or cytokines are released in the first hours after the surgical procedure (NAUMANN \& SAUTTER, 1988; KOCH, 1992) with vessels in the cornea 2 to 4 days after the loss of epithelium and stroma (PEIFFER JR. et al., 1999).

Corneal vascularization favors the cicatricial process, including tissue remodeling (EPSTEIN et al, 1987). On the other hand, it is not desirable due to the loss of corneal transparency (PEIFFER JR. et al., 1999). Several trials have been performed in order to evaluate aspects related to corneal vascularization (SUNDERKOTTTER et al., 1991a; REHANY \& WAISMAN, 1994; KENYON et al., 1996; BENELLI et al., 1997; BARROS et al., 2000) and several therapeutic schemes were attempted in order to decrease or inhibit it, mainly the topic or systemic administration of cyclosporine A at different concentrations (LIPMAN et al., 1992; REHANY \& WAISMAN, 1994; BENELLI et al., 1997).

Cyclosporine A is a cyclic polypeptide from the fungus Tolypocladium inflatum Gans, and presents the ability to inhibit the activation and proliferation of T-helper lymphocytes, by blocking the release of lymphokines (DIASIO \& LOBUGLIO, 1996). It was successfully used in topic treatment, decreasing the neovascularization in the cornea of $\operatorname{dog} s$ presenting keratoconjunctivitis sicca (KASWAN et al., 1989). It also reduced corneal vascularization that developed in mice after an intracorneal injection of interleukin-2, when intramuscularly administered (LIPMAN et al., 1992). Ciclosporine A given subcutaneously also has been found to supress new vessel formation induced in the mesenteric-window assay in rats (NORRBY, 1992). It also is reported to produce clinical improvement in psoriasis and certain epithelial neoplasms in which angiogenesis is proeminent (NORRBY, 1992). It decreased the growth of vessels in the cornea of rats after xenotransplantation and chemical cauterization using silver nitrate, when a $4 \%$ solution was topically and systematically administered. However, it was not effective in the blockage of new vessels growth induced by the insertion of an angiogenic disc in the subcutaneous tissue, when systematically or intradisc administered (BENELLI et al., 1997).

Topical administration of cyclosporine A does not produce a measurable systemic concentration or contralateral ocular immunusupression (FOETS et al., 1985; BELIN et al., 1990; JACKSON et al., 1991; BENELLI tet al., 1997; STEVENSON et al., 2000)enabling each animal to be its own control (JACKSON et al., 1991).

Cyclosporine A 2\% did not inhibit or decrease the formation of vessels in this trial, although it may have showed anti-angiogenic or angiostatic activity in other studies (LIPMAN et al., 1992; NORRBY, 1992; BENELLI et al., 1997). The mechanisms by which cyclosporine A reduces or inhibits angiogenesis in some, but not in all models, remain unrecognized (BENELLI et al., 1997). One of the hypothesis is that it may be related to the nature and the permanence of the injury; to the quality and time of the surgical procedure and to the kind of suture used (NASISSE, 1985; KERN, 1990). Therefore, the angiogenic response may vary significantly according to these characteristics, to the species involved, to the type of biological membrane used and to its particular angiogenic ability (BARROS et al., 2000). 
Cyclosporine A inhibits only the transcription of the genes for interleukin-2 (IL-2) and interleukin-4 (IL-4) (RIZZO, personal communication, 2000). Thus, the other lymphokines (DIASIO \& LOBUGLIO, 1996; ROOK \& BALKWILL, 1999; GOLDSBY, 2000a) may produce angiogenic effects, what could explain the similarity between the control and treated corneas on the $3^{\text {rd }}, 7^{\text {th }}$ and $60^{\text {th }}$ postoperative day. Cyclosporine A also increases the expression of TGF- $\beta$, (PRASHAR et al., 1995; KHANNA et al., 1997; SHIN et al., 1998) which presents evident angiogenic effects (ROBERTS et al., 1986; SUNDERKOTTER et al., 1991b).

It is important to note that, during the cicatricial process, epithelial cells, keratocytes and stromal fibroblasts may also synthesize and release growth factors with angiogenic activity (SWANK \& HOSGOOD, 1996).

As it is know that several cells take part in the angiogenesis phenomenon, and although lymphocytes are relevant in this process, macrophages are also very important due to their intense secretion of factors that may be directly or indirectly angiogenic, contributing with more than one factor at each stage of the angiogenesis (POLVERINI et al., 1977), what may compensate for the angiogenic effects of the lymphokines blocked by cyclosporine A.

The occurrence of a more intense vascularization process on days 15 and 30 in the corneas treated with cyclosporine A $2 \%$ may be due to the combined action of the angiogenic cytokines secreted by macrophages and those released by the lymphocytes and not affected by cyclosporine, together with the increase of TGF- $\beta$ expression (PRASHAR et al., 1995; KHANNA et al., 1997; SHIN et al., 1998). Another possibility is that, because of the inhibition of the synthesis and release of IL-2 and IL-4, and of the increase of TGF- $\beta$ expression, both caused by cyclosporine $A$, there would be an unbalance between angiogenic and anti-angiogenic factors. This balance is extremely important for the control of angiogenesis, which is dose-dependent (STRIETER et al., 1992). Therefore, it may affect the secretory pattern of lymphocytes and macrophages, what would result in the increase in angiogenic cytokine release by these cells.

In relation to the inflammatory reaction, cell infiltrate was characterized by the invasion of the site with polymorphonuclear and mononuclear lymphocytes. Neutrophils were the most prevalent in the beginning of the inflammatory process, followed by monocytes and lymphocytes that also migrated to the site of injury. The early inflammatory cell infiltrated is considered a pre-requisite for angiogenesis induction (SUNDERKOTTER et al., 1991a), for it acts in the degradation of proteins from the extracellular matrix and would justify the beginning of the vascularization process as early as the $3^{\text {rd }}$ postoperative day, bilaterally.

An important stage in leukocyte migration is the fixation of the cells to the vascular endothelium, as a consequence of the interaction between the molecules on the membranes of the leukocytes with the corresponding molecules on the activated endothelium (SPENCER, 1996), controled by the expression of the adhesion molecule E-selectin on the surface of the endothelium (KOCH et al., 1995). It has recently been suggested that this molecule presents direct angiogenic effect on the endothelial cells ( $\mathrm{KOCH}$ et al., 1995) and that cyclosporine A may promote the low regulation of the expression of this molecule by the vascular endothelium, what would suppress the growth of vessels (BENELLI et al., 1997). In the present trial, however, inflammatory cell infiltrate was observed as early as the $3^{\text {rd }}$ postoperative day, and was bilaterally evident up to day 60 . This would confirm that cyclosporine A did not present any effect on this adhesion molecule. It is important to emphasize that cytokines TNF- $\alpha$ and IL-1, which stimulate the secretion of E-selectin by the endothelium $(\mathrm{KOCH}$ et al., 1995; GOLDSBY, 2000b) are not affected by cyclosporine A.

\section{CONCLUSIONS}

Lamellar keratectomy with equine pericardium graft preserved in $98 \%$ glycerin was a feasible model for the study of inflammation kinetics and angiogenesis phenomenon in the cicatricial reaction of the cornea. There was intense vascularization and an important fibroblast response, with the permanence of cicatricial leucoma and corneal vessels on the $60^{\text {th }}$ postoperative day.

Cyclosporine A $2 \%$ did not interfere in the corneal cicatricial process generated by keratoplasty with lamellar equine pericardium graft. It also did not decrease the corneal vascularization process in this study.

\section{ACKNOWLEDGMENTS}

This paper was presented to the Faculdade de Medicina Veterinária e Zootecnia at Universidade de São Paulo by Dr. Teixeira to obtain her MSc Degree. The project was supported by Fundação de Amparo à Pesquisa do Estado de São Paulo (FAPESP), fellowship grant number 98/06611-0. The authors thank Prof. Dr. Luiz Vicente Rizzo, from the 
Department of Immunology at the Instituto de Ciências Biomédicas at Universidade de São Paulo, for his helpful comments, and Prof. Dr. Dennis E. Brooks, from University of Florida - U.S.A., for critical review of this manuscript. RIZZO, L.V. Personal communication. Department of Immunology at the Instituto de Ciências Biomédicas at Universidade de São Paulo, São Paulo-SP, Brazil, 2000. E-mail: 1vrizzo@icb.usp.br

\section{ACQUISITION}

* 2\% Cyclosporine ointment: Ophthalmos - São Paulo - SP Brazil. E-mail: farmbrig@ amcham.com.br

\section{REFERENCES}

BARROS, P. S. M.; ALVARENGA, J.; STOPIGLIA, A. J. The use of pericardium in the correction of entropion and the filling of the canine orbital cavity following enucleation. The Internacional Society of Veterinary Ophthalmology Newsletter, v.3, p.4, 1985.

BARROS, P.S.M. et al. The repair of the esclera and third eyelid using heterologous pericardium. A experimental study. In: AMERICAN SOCIETY OF VETERINARY OPHTHALMOLOGY AND INTERNACIONAL SOCIETY OF VETERINARY OPHTHALMOLOGY, 1990, San Francisco. Program... San Francisco : International Society of Veterinary Ophthalmolgy, 1990. p.11-12.

BARROS, P.S.M. et al. The surgical repair of the cornea of the dog using pericardium as a keratoprosthesis. Brazilian Journal of Veterinary Research and Animal Science, v.32, n.4, p.251-255, 1995.

BARROS, P.S.M. et al. Comparative study of the angiogenic capacity of the amniotic membrane and pericardium in the cornea of rats. Investigative Ophthalmology and Visual Science, v.41, p.S455, 2000.

BARROS, P.S.M.; SAFATLE, A.M.V.; RIGUEIRO, M. Use of horse pericardium preserved in glycerin as corneal graft in dogs. Experimental study. Brazilian Journal of Veterinary Research and Animal Science, v.34, n.3, p.138-141, 1997.

BELIN, M.W. et al. Update on topical Cyclosporin A. Cornea, v.9, n.3, p.184-195, 1990.

BEHRENS-BAUMAN, W.; THEURING, S.; BREWITT, H. The effect of topical cyclosporin A on rabbit cornea: a clinical and electron microscopic study. Graefes Archives of Clinical and Experimental Ophthalmology, v.224, p.520524,1986

BENELLI, U. et al. Corneal neovascularization induced by xenografts or chemical cautery: Inhibition by cyclosporin A. Investigative Ophthalmology and Visual Science, v.38, n.2, p.274-282, 1997.

BROOKS, D.E. Keeping the windshield clean: aggressive treatment of corneal disease in the dog and cat. In: NORTH AMERICA VETERINARY CONFERENCE - SMALL ANIMAL, 2000, U.S.A. Abstracts... Florida : International Society of Veterinary Ophthalmology, 2000. p.10-13.
DIASIO, R.B.; LOBUGLIO, A.F. Immunomodulators: Immunosupressive agents and immunostimulants. In: HARDMAN, J.G.; GOODMAN GILMAN, A.; LIMBIRD, L.E. The farmacological basis of therapeutics. 9.ed. New York : Library of Congress Cataloging, 1996. p.1291-1304.

EPSTEIN, R.J. et al. Corneal neovascularization: Pathogenesis and inhibition. Cornea, v.6, n.4, p.250-257, 1987.

FOETS, B.; MISSOTTEN, L.; VANDERVEEREN, P. Prolonged survival of allogeneic corneal grafts in rabbits treated with topically applied cyclosporin A: systemic absorption and local immunosuppressive effect. British Journal of Ophthalmology, v.69, p.600-603, 1985.

GOLDSBY, R.A. Cell-mediated effector responses. In: GOLDSBY, R.A.; KINDT, T.J.; OSBORNE, B.A. Immunology. 4.ed. New York : Freeman, 2000a. p.351369.

GOLDSBY, R.A. Leucocyte migration and inflamation. In: GOLDSBY, R.A.; KINDT, T.J.; OSBORNE, B.A. Immunology. 4.ed. New York : Freeman, 2000b. p.371391.

JACKSON, P.A. et al. Chronic superficial keratitis in dogs: a placebo controlled trial of topical cyclosporine treatment. Progress in Veterinary and Comparative Ophthalmology, v.1, n.4, p.269-275, 1991.

KASWAN, R.L.; SALLISBURY, M.A.; WARD, D.A Spontaneous canine keratoconjuctivitis sicca. A useful model for human keratoconjunctivitis sicca: treatment with cyclosporine eye drops. Archives of Ophthalmology, v.107, p.1210-1216, 1989.

KAVINSKI, L.C. Pericardium patch grafts for treatment of corneal lesions in dogs. In: WORLD CONGRESS OF THE WORLD SMALL ANIMAL VETERINARY ASSOCIATION, 7., NATIONAL CONGRESS OF AVEPA, 14., 1980, Barcelona. Proceedings... Barcelona: $7^{\text {th }}$ World Congress of the World Small Animal Veterinary Association, 1980. p.17.

KERN, T.J. Ulcerative keratitis. Veterinary Clinics of North America Small Animal Practice, v.20, n.3, p.643-666, 1990.

KHANNA, A. et al. In vivo hyperexpression of transforming growth factor-beta1 in mice: stimulation by cyclosporine. Transplantation, v.63, n.7, p.1037-1039, 1997.

KENYON, B.M. et al. A model of angiogenesis in mouse cornea. Investigative Ophthalmology and Visual Science, v.37, n.8, p.1625-1632, 1996.

KOCH, A.E. Interleukin-8 as a macrophage-derived mediator of angiogenesis. Science, v.258, p.1798-1801, 1992.

$\mathrm{KOCH}$, A.E. et al. Angiogenesis mediated by soluble forms of E-selectin and vascular cell adhesion molecule-1. Nature, v.376, n.10, p.517-519, 1995.

LIPMAN, R.M.; EPSTEIN, R.J.; HENDRICKS, R.L. Suppression of corneal neovacularization with cyclosporine. Archives of Ophthalmology, v.110, p.405-407, 1992. 
MORGAN, R.V.; ABRAMS, K.L. Topical administration of cyclosporine for treatment of keratoconjunctivitis sicca. Journal of the American Veterinary Medical Association, v.199, n.8, p.1043-1046, 1991.

NASISSE, M.P. Canine ulcerative keratitis. Compendium on Continuing Education for the Practicing Veterinarian, v.7, n.9, p.686-701, 1985.

NAUMANN. G.O.H.; SAUTTER, H. Surgical procedures on the cornea. In: BLODI, F.C.; MACKENSEN, G.; NEUBAUER, H. Surgical ophthalmology. Berlin : Springer-Verlag, 1988. v.1. p.434-440.

NORRBY, K. Cyclosporine is angiostatic. Experimentia, v.48, p.1135-1138, 1992.

PEIFFER JÚNIOR, R.L. et al. Fundamentals of veterinary ophthalmic pathology. In: GELATT, K.N. Veterinary ophthalmology. 3.ed. Philadelphia : Lippincott Williams \& Wilkins, 1999. p.355-385.

POLVERINI, P. et al. Ativated macrophages induce vascular proliferation. Nature, v.269, n.5631, p.804-806, 1977.

PRASHAR, Y. et al. Stimulation of transforming growth factorbeta 1 transcription by cyclosporine. FEBS, Lett, v.358, n.2, p.109-112, 1995.

READ, R.A. Cyclosporin and its treatment of ophthalmic diseases in animals. Australian Veterinary Practice, v.26, n.2, p.86-91, 1996.

REHANY, U.; WAISMAN, M. Suppression of corneal allograft rejection by systemic cyclosporine-A in heavily vascularized rabbit corneas following alkali burns. Cornea, v.13, n.5, p.447453, 1994.

ROBERTS, A.B. et al. Transforming growth factor type $\beta$ : rapid induction of fibrosis and angiogenesis in vivo and stimulation of collagen formation in vitro. In: NATIONAL ACADEMY OF SCIENCE, 83., 1986, U.S.A. Proceedings... Philadelphia : National Academy of Science, 1986. p.4167-4171.
ROOK, G.; BALKWILL, F. Reações imunes mediadas por células. In: ROIT, I.; BROSTOFF, J.; MALE, D. Imunologia. São Paulo : Manole, 1999. p.121-135.

RYFFEL, B. Pharmacology of cyclosporine VI. Cellular activation: Regulation of intracellular events by cyclosporine. Pharmacology Review, v.41, p.407-422, 1989.

SHIN, G. T. et al. In vivo expression of transforming growth factor-beta1 in humans: stimulation by cyclosporine. Transplantation, v.65, n.3, p.313-318, 1998.

SPENCER, W.H. Cornea. In: ______. Ophthalmic pathology. 4.ed. Philadelphia: Saunders, 1996. p.157-333.

STARTUP, F.G. Corneal ulceration in the dog. Journal of Small Animal Practice, v.25, p.737-752, 1984.

STEVENSON, D.; TAUBER, J.; REIS, B.L. Efficacy and safety of cyclosporin A ophthalmic emulsion in the treatment of moderate to severe dry eye disease. Ophthalmlogy, v.107, n.5, p.967-974, 2000.

STRIETER, R.M. et al. Interleukin-8. A corneal factor that induces neovascularization. American Journal of Pathology, v.141, n.6, p.1279-1284, 1992.

SUNDERKOTTER, C. et al. Cellular events associated with inflamatory angiogenesis in the mouse cornea. American Journal of Pathology, v.138, n.4, p.931-939, 1991a.

SUNDERKOTTER, C. et al. Macrophage-derived angiogenesis factors. Pharmacological Therapy, v.51, p.195-216, $1991 \mathrm{~b}$.

SWANK, A.; HOSGOOD, G. Corneal wound healing and the role of growth factors.Compendium on Continuing Education for the Practicing Veterinarian, v.18, n.9, p.1007-1016, 1996.

WARING, G.O. Corneal structure and pathophysiology. In: LEIBOWITZ, $H$. Corneal disorders: clinical diagnosis and management. Philadelphia : Saunders, 1984. p. $3-25$. 